\title{
Jordanian EFL Students' Types of Intelligence in Learning English
}

\section{Sana’ Ababneh}

Associate Professor, Basic Sciences Department, Al-Balqa Applied University, Jordan. Email:ababneh_sanaa@yahoo.com Tel: +962795211332

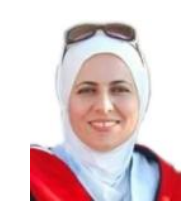

\begin{abstract}
The present study investigated the types of intelligence BAU students prefer to use in learning English. This study used a quantitative method for collecting data via a questionnaire. The subjects of the study were 138 Jordanian students at Al-Huson University College, Al-Balqa Applied University. The results revealed that logical-mathematical and linguistic intelligence was the most dominant type of intelligence among the students. However, neither their gender nor their academic degree program had a significant effect on their learning type of intelligence. Nevertheless, the data showed substantial differences among the students in the interpersonal type of intelligence in favor of male students, while these differences were in favor of the females in the intrapersonal type. There were significant differences in the logical-mathematical type of intelligence between the bachelor's degree students and their diploma colleagues in favor of the bachelor ones. The researcher attempts to shed light on Jordanian EFL students' types of intelligence and their preferred types when learning English, in hopes that it becomes possible for teachers to recognize the types according to their students' profiles and help match them with those present or assess whether they need to develop strategies to cover the full spectrum of the types found in MI Theory.
\end{abstract}

Keywords: Types of intelligence, EFL, TEFL, Learning / teaching strategies, Gender, Jordan.

Citation | Sana' Ababneh (2021). Jordanian EFL Students' Types of Intelligence in Learning English. Journal of Education and eLearning Research, 8(3): 360-366.

History:

Received: 8 November 2020

Revised: 29 July 2021

Accepted: 23 August 2021

Published: 17 September 2021

Licensed: This work is licensed under a Creative Commons

Attribution 3.0 License $($ oc)

Publisher: Asian Online Journal Publishing Group
Funding: This study received no specific financial support.

Competing Interests: The author declares that there are no conflicts of interests regarding the publication of this paper.

Transparency: The author confirms that the manuscript is an honest, accurate, and transparent account of the study was reported; that no vital features of the study have been omitted; and that any discrepancies from the study as planned have been explained.

Ethical: This study follows all ethical practices during writing.

\section{Contents}

1. Introduction 


\section{Contribution of this paper to the literature}

This paper is the first to investigate the types of intelligence of Jordanian EFL students in learning English.

\section{Introduction}

In this paper, the idea of having weak students or poor learners is questioned. The researcher argues that students should not be classified as poor/weak learners and good ones and instead it should be realized that there are various types of intelligence, and each student is intelligent in their way, and can learn better according to their type of intelligence. From this point of view, having weak learners could be overcome by using the appropriate method of teaching that matches the intelligence type each learner possesses.

The Multiple Intelligences Theory was developed in 1983 by Gardner. According to Gardner's theory, different intelligence capacities result in many ways of knowing, understanding, and learning about our world. Multiple intelligence theory perceives intelligence in a new way that recognizes many different and discrete facets of cognition and acknowledging that people have different strengths and contrasting cognitive styles (Derakhshan $\&$ Faribi, 2015).

Research on intelligence led to changing the traditional view of intelligence that was built mainly upon using IQ tests that only measured two types of intelligence which are (1) linguistic and (2) logical-mathematical intelligence (Brown, 2002). This served in favor of considering other types that cannot be measured using IQ tests but are as important or perhaps of more importance to functioning tasks of our daily lives such as problem-solving or learning a foreign language. In the same vein, Brown (2001) claims that there has been a shift in the view on intelligence from "the ability to perform (a) linguistic and (b) logical-mathematical problem solving" to including five other types which are namely: spatial, musical, bodily-kinesthetic, interpersonal and intrapersonal intelligence. Gardner (1993) argued that everyone is born possessing these seven types of intelligence.

\subsection{Types of Intelligence}

Gardne (1999) cited in Altan (2012) listed seven intelligence as follows:

1. Linguistic Intelligence: Speaking and writing, using words, the ability to learn languages. Lawyers, speakers, writers, are among the people who possess such type of intelligence.

2. Logical/Mathematical Intelligence: analyzing problems logically, using numbers, logic, and understanding grammar rules (Brown, 2002). Mathematicians and scientists are good examples of this type.

3. Visual/Spatial Intelligence: Drawing and using color, art, graphics, and maps. Sample skills include perceiving from different angles, recognizing spatial relationships, image manipulation, active imagination, (Altan, 2012).

4. Bodily/Kinesthetic Intelligence: Muscular coordination, body language, pronouncing a language (Brown, 2002). Dancers, actors, and athletes are foregrounded in this intelligence (Altan, 2012).

5. Musical Intelligence: Using music, producing rhythm, pitch, and melody. Sample skills include recognizing the structure of music, sensing qualities of a tone (Altan, 2012).

6. Interpersonal Intelligence: Talking with other people and using a language to communicate well with other people (Brown, 2002). Salespeople, teachers, clinicians, religious and political leaders need this intelligence (Altan, 2012).

7. Intrapersonal Intelligence: using language to analyze oneself, including one's desires, fears, and capacities. Sample skills include a transpersonal sense of the self, awareness, and expression of different feelings, understanding how one is like or different from others, higher-order thinking/ reasoning (Altan, 2012).

A question that is raised is how we can incorporate Multiple Intelligences Theory into EFL classrooms. One possible answer to this question is to identify the students' types of intelligence to find a suitable classroom methodology that reflects the strengths and weaknesses of students, taking into consideration the types of intelligence that the majority of the class has and those on the individual level. Based on this information, educators can prepare specific intelligence-based lessons by integrating Multiple Intelligences Theory into the teaching of EFL classrooms. This means that each element of EFL taught in class should be presented in two or three different approaches based on the preferred multiple intelligence learning types of the students. The idea is to adapt the perfect theme to suit the intelligence of three or four types of learners in a classroom. This should quite effectively cover the multiple intelligence of all the learners in even the largest of EFL student groups.

\subsection{Significance of the study}

The significance of the present study stems from the fact that most Jordanian students and teachers have difficulties learning/teaching English. Many students fail their English exams and have negative attitudes towards learning English (Ababneh, 2017). By extrapolating results of this study, the researcher tries to spot the light on Jordanian EFL students' preferred types of intelligence when learning English, in hopes that it becomes possible for teachers to recognize the types according to their students' profiles. This can help them to match them with those present or assess whether they need to develop other strategies to cover the full spectrum of the types found in MI Theory. Thus, making it possible to bridge the gap between students' needs in learning English on the one hand and their academic performances on the other.

The multiple intelligence theory serves to broaden the perspectives of educators, students, textbook authors, etc. to acknowledge that people possess one or more types of intelligence. Thus, students' types of intelligence should be first recognized and assessed so that the right methods, activities, and tasks pertinent to their type of intelligence are incorporated in the curricula to help them learn a foreign language amongst other educational endeavors. The study investigates the effect of students' gender and academic degree programs on these types of intelligence. A clear picture of students' types of intelligence may inspire English language teachers as well as curriculum designers to prepare appropriate teaching materials that cater to all types of intelligence among learners. It is well acknowledged that language can be taught better if teachers create innovative and effective ways 
of teaching that incorporate new trends that cater to students' needs and learning preferences and their respective multiple intelligences (Sólmundardóttir, 2008).

\subsection{Questions of the Study}

1. What types of intelligence do BAU students prefer to use in learning English?

2. Are there any statistically significant differences between BAU students' intelligence types that they prefer to use in learning English in terms of gender?

3. Are there any statistically significant differences between BAU students' intelligence types that they prefer to use in learning English in terms of the academic degree programs (bachelor/ diploma)?

\subsection{Limitations of the Study}

The present study suffers from the following limitations. First, it can be applied only to Jordanian EFL students registered in one course, namely English 101, taught in one college. Including other courses and other institutions could have yielded more reliable results. Secondly, the small number of subjects in the sample. A larger sample could have provided different results.

\section{Literature Review}

Xhomara and Shkembi (2020) tried to investigate the relationship between learning styles and multiple intelligence. The researchers studied the verbal-linguistic, logical-mathematical, musical, spatial-visual, bodilykinesthetic, interpersonal, intrapersonal, and naturalist intelligence as independent variables. The dependent variables were auditory, visual, and kinesthetic learning styles. The primary inquiry of the study was to find out if there were any associations between the dependent and the independent variable. The findings of this research revealed that there is a strong association between multiple intelligence and learning styles. This study suggested some implications of significance, such as designing and developing teaching programs based on incorporating the multiple intelligence theory to assist students' skills because there is strong evidence on the positive correlation between learners' multiple intelligence and their learning styles.

Sadiq (2019)'s study aimed to discover the relationship between the analytic side of MI theory and the English objective tests. The results revealed a weak correlation between those two factors. The researcher suggested that English objective tests given in Baghdad University should be modified according to the MI theory to meet students' skills and types of intelligence since such tests did not "reflect students' abilities and intelligence" (p.166). She also calls for implementing other tests to assess English because objective tests mainly focus on retention and memorization.

Winarti, Yuanita, and Nur (2019) conducted a study to shed light on implementing multiple intelligence theory in teaching as they believed that teachers neglected its importance in developing the learning process and students' learning abilities. They developed a teaching strategy in science classes based on the multiple intelligence theory. Results obtained from their study proved that the implementation of the IM theory in teaching Science had improved students' learning abilities and personal skills. They believe that implementing the IM theory in teaching "contributes to improving the quality of science learning in the future. Learning is no longer oriented to improving academic ability only, but also attempted to improve the science process skill and potential of students." (p.132)

Alrabah, Wu, and Alotaibi (2018) explored Kuwaiti college students' learning styles and multiple intelligences in learning English. They found out that the students' most-used learning styles were" global, extroverted, handson, and visual" (p.38), while their most influential multiple intelligences were" interpersonal, visual, and kinesthetic". (p.38). The researchers recommended using some teaching activities like "role plays, simulations, and debates." (p.38)

Dolati and Tahriri (2017) investigated the effect of the different types of intelligence of EFL instructors on the activities that they use in their classrooms. They also studied those instructors' perceptions of the multiple intelligence theory. Results of their study showed that nearly all the instructors are not aware of the existence of the MI theory, and they never used it in their classes. The study revealed that only the instructors who enjoy logical-mathematical type were affected by their controlling intelligence type while the other types of intelligence did not show any effect on the activities' types used by those instructors.

Alqatanani (2017) study examined the probable influence of a teaching program designed according to multiple intelligences theory on developing the critical reading skills of Jordanian EFL students. The researcher found out that the multiple intelligences theory-based program has significantly affected the students reading skills positively. He also called teachers to incorporate the multiple intelligences theory in their classes to meet their students' needs and open new teaching experiences and avenues that guarantee better learning.

Arnold and Fonseca (2004) claimed that the Multiple Intelligence Theory (MI) has shown improving academic results in different disciplines such as foreign language teaching since it is not enough in today's language classroom to promote solely the linguistic or even the communicative competence. In the same vein, according to (Snider, 2001) "MI Theory- related materials have the strong potential to improve foreign language (FL) instruction because they engage learners' innate abilities."

Tawalbeh (2016) investigated EFL Saudi learners' multiple intelligences to provide suggestions for EFL instructors to integrate multiple intelligence into their lesson plans for instructional use in their classrooms. His study revealed that the subjects do not show interest in both musical and naturalistic intelligence. The data showed significant differences between the subjects' perceptions of their multiple intelligences in favor of the health stream as opposed to the humanities and scientific streams.

Kentab (2016) conducted research investigating the perspectives of Saudi intermediate English language teachers of the multiple intelligence theory. The study aimed at investigating the difficulties which prevent implementing the multiple intelligences among intermediate school students from the point of view of their teachers. Also, the study catered for the influence of multiple intelligences on Saudi students' comprehension of English as a foreign language. The findings of this research showed that multiple intelligences theory created new 
experiences that fulfilled the various needs and styles of Saudi students. It gave the teachers the chance to explore and be aware of their students' learning needs, abilities, and experiences.

Yoones, Ahmadreza, and Farzane (2014) investigated the Iranian domestically designed and published English Language Teaching (ELT) textbooks in the light of multiple intelligences theory. Results of their study revealed that verbal-linguistic intelligence and visual-spatial intelligence were the most predominant intelligence followed by logical-mathematical intelligence, interpersonal intelligence, and intrapersonal intelligence were in much lower ratios. Bodily / kinesthetic, musical, and naturalistic intelligence was not found in any percent. Besides, the study showed that students' intelligence profiles were far from the types the textbooks were designed for.

Yoones, Adnan, and Hamid (2014) in another study, examined English as a foreign language students' profiles and their textbooks using multiple intelligence theory to identify the intelligence type incorporated in English language teaching textbooks and the preferences of the students to different types of intelligence. The findings of their study showed that teaching textbooks are mostly provided for verbal-linguistic, interpersonal, visual, spatial, and logical-mathematical intelligence. As for students' preferences of the intelligence types, the study revealed that they preferred all types of intelligence in varying degrees. The most preferred types were interpersonal and logicalmathematical types.

Abdul Razak and Zaini (2014) studied the connection between multiple intelligences on the one hand, and the reading proficiency of science stream Malaysian students on the other side. The researchers aimed to discover the dominant type of intelligence used by the subjects of their study. The results showed a strong connection between students' proficiency in reading with "Music-Rhythmic, Bodily-Kinesthetic and Interpersonal” Intelligences. p. (63)

Kırkgöz (2010) investigated the extent to which English textbooks that are locally designed for primary education in Turkish state schools reflected the Multiple Intelligences. The researcher developed a checklist based on the framework of the Theory of Multiple Intelligence to examine English textbooks. The results of his research showed that the intelligence profile of English textbooks is predominantly verbal/linguistic and visual/spatial. The results also revealed that the least occurring intelligence type was the naturalistic one. No activities were found that catered for the existentialist learners in any of the textbooks, neither for a fair percentage of distribution for the remaining types of intelligence understudy.

Urooj and Malik (2012) analyzed the primary level of English textbooks concerning Gardner's multiple intelligence theory. They also explored the ways for integrating all multiple intelligence into the textbooks of English of the primary schools, and they encouraged the teachers to promote multiple intelligence on the teaching of the English curriculum. The findings of their study depict that linguistic intelligence is predominantly focused on. They recommended that other types of intelligence, such as interpersonal, intrapersonal, bodily-kinesthetic, and musical, should be promoted and incorporated into English textbooks.

Zarei and Afshar (2014) conducted a study investigating types of multiple intelligence as predictors of reading comprehension and vocabulary knowledge. They used a 60-item TOEFL test and a 90- item multiple intelligences questionnaires in an Iranian context. The findings of their study showed that musical, interpersonal, kinesthetic, and logical intelligence were indicators of reading comprehension. Musical, verbal, kinesthetic, and natural intelligence had significant contributions in predicting vocabulary knowledge.

\section{The Methodology of the Study \\ 3.1. Sample of the Study}

The subjects of the present study were purposely chosen from the students registered in the Second Semester of the Academic Year 2018/2019 in English 101, a course taught at the Basic Sciences Department, at Al-Huson University College, Al-Balqa Applied University, Jordan. The sample consisted of 138 Jordanian students: 49 female students and 89 male students, who were registered in two separate sections; one for bachelor students, the total number of the bachelor section was 89 and the other one for diploma students who were 49 . The two sections were taught by the same professor, and they use the same textbook.

\subsection{The Instrument of the Study}

The primary method of inquiry used in this study was a questionnaire written in English. It consisted of fourteen statements. In front of each statement, four choices that describe students' language learning intelligence type are provided. The researcher adopted this questionnaire from Brown (2002).

The researcher wanted to identify Jordanian EFL students' types of intelligence in learning English, and to find out any differences between their intelligence types in terms of their gender, or academic degree program.

The researcher kindly asked the participants to fill in their responses and responded to their inquiries about the questionnaire statements.

\subsection{Data Collection}

Before handing out the questionnaire, the researcher informed the students about the objectives and the importance of the research, and they were advised not to declare their identity. The students were told that their responses to the questionnaire statements would not be disclosed. They were also asked to give genuine and authentic responses.

\subsection{Data Analysis}

To determine the participants' type of intelligence in learning English, the researcher used the mean scores and the standard deviations of their responses on the questionnaire statements. The T-test was used to investigate the effect of gender or the academic degree program of the participants' types of intelligence. 


\section{Findings and Discussions}

This section aims to present the findings that represent the answers to the questions of the study. Students' responses to the questionnaire were the basis for analyzing the data of this study. The first question being: What types of intelligence do BAU students prefer to use in learning English?

Table-1. Mean scores and standard deviations of students' preference for using each type of intelligence in learning English.

\begin{tabular}{l|c|c|c}
\hline Type of intelligence & Mean Scores & Sd & Score of preference \\
\hline Linguistic intelligence & 6.12 & 1.25 & Very high \\
\hline Logical-mathematical intelligence & 6.30 & 1.17 & Very high \\
\hline Spatial intelligence & 5.64 & 1.34 & Moderately high \\
\hline Bodily-kinesthetic intelligence & 4.89 & 1.52 & Moderately high \\
\hline Musical intelligence & 4.74 & 1.74 & Moderately high \\
\hline Interpersonal intelligence & 5.99 & 1.43 & Moderately high \\
\hline Intrapersonal intelligence & 5.91 & 1.37 & Moderately high \\
\hline Note: * Preference score key: 7-8 (very high), 5-6 (moderately high), 3-4(moderately low), 1-2(low preference).
\end{tabular}

As shown in Table 1, the participants' mean scores are between 4.74 and 6.30. Also, the logical-mathematical type of intelligence got the highest mean score, while the lowest score was for the musical type of intelligence.

The second question was if there were any statistically significant differences between BAU students' types of intelligence due to their gender. Table 2 presents the results.

The second question raised in this study was if there were any statistically significant differences between BAU students' types of intelligence due to their gender. The researcher did a $t$-test for equality between the means of the subjects' responses on the questionnaire statements regarding their types of intelligence that they prefer to use in learning English regarding their gender. Table 2 presents the results.

\begin{tabular}{|c|c|c|c|c|c|c|}
\hline Type of intelligence & Gender & $\mathbf{N}$ & Mean & Sd & $\mathbf{T}$ & P-Value \\
\hline \multirow[t]{2}{*}{ Total } & Male & 89 & 5.68 & .715 & \multirow[t]{2}{*}{0.064} & \multirow[t]{2}{*}{0.949} \\
\hline & Female & 49 & 5.67 & .777 & & \\
\hline \multirow[t]{2}{*}{ Linguistic intelligence } & Male & 89 & 5.98 & 1.31 & \multirow[t]{2}{*}{-1.87} & \multirow[t]{2}{*}{0.064} \\
\hline & Female & 49 & 6.39 & 1.10 & & \\
\hline \multirow[t]{2}{*}{ Logical-mathematical intelligence } & Male & 89 & 6.42 & 1.14 & \multirow[t]{2}{*}{1.62} & \multirow[t]{2}{*}{0.108} \\
\hline & Female & 49 & 6.08 & 1.20 & & \\
\hline \multirow[t]{2}{*}{ Spatial intelligence } & Male & 89 & 5.69 & 1.43 & \multirow[t]{2}{*}{0.475} & \multirow[t]{2}{*}{0.635} \\
\hline & Female & 49 & 5.57 & 1.19 & & \\
\hline \multirow[t]{2}{*}{ Bodily-kinesthetic intelligence } & Male & 89 & 4.88 & 1.54 & \multirow[t]{2}{*}{-0.155} & \multirow[t]{2}{*}{0.877} \\
\hline & Female & 49 & 4.92 & 1.50 & & \\
\hline \multirow[t]{2}{*}{ Musical intelligence } & Male & 89 & 4.73 & 1.68 & \multirow[t]{2}{*}{-0.080} & \multirow[t]{2}{*}{0.937} \\
\hline & Female & 49 & 4.76 & 1.85 & & \\
\hline \multirow[t]{2}{*}{ Interpersonal intelligence } & Male & 89 & 6.18 & 1.47 & \multirow[t]{2}{*}{2.17} & \multirow[t]{2}{*}{$0.032 *$} \\
\hline & Female & 49 & 5.63 & 1.32 & & \\
\hline \multirow[t]{2}{*}{ Intrapersonal intelligence } & Male & 89 & 5.89 & 1.44 & \multirow[t]{2}{*}{-0.210} & \multirow[t]{2}{*}{0.834} \\
\hline & Female & 49 & 5.94 & 1.23 & & \\
\hline
\end{tabular}

Results obtained from Table 2 show the following:

1- There are no significant differences between students' types of intelligence that they prefer to use in learning English due to their gender in general because the T-value is 0.064 , and the P-value is 0.949 at $\alpha \leq 0.05$.

2- There are no significant differences between students' types of intelligence that they prefer to use in learning English due to their gender regarding (a) linguistic intelligence, (b) logical-mathematical intelligence, (c) spatial intelligence, (d) bodily-kinesthetic intelligence, (e) musical intelligence.

3- There are significant differences between students' types of intelligence that they prefer to use in learning English due to their gender on the interpersonal intelligence in favor of male students since the t-value is 2.17, and the p-value is 0.032 which is less than 0.05 .

4- There are significant differences between students' types of intelligence that they prefer to use in learning English due to their gender on the intrapersonal intelligence in favor of female students since the t-value is $(-$ 0.210 ), and the p-value is 0.834 which is more than 0.05 .

The third question presented in this study was investigating if there were any statistically significant differences between BAU students' types of intelligence that they prefer to use in learning English in terms of their academic degree program (bachelor/ diploma). To this end, a t-test between the means of the students' responses on the questionnaire statements was used. Table 3 shows the results.

Data obtained from Table 3 shows the following:

1- There are no significant differences between students' types of intelligence that they prefer to use in learning English due to their academic degree program (bachelor/ diploma) in general because the T-value is -.133 and the $\mathrm{P}$-value is .894 which is more than 0.05 .

2. There are significant differences between students' types of intelligence that they prefer to use in learning English due to their academic degree program (bachelor/ diploma) on the logical-mathematical intelligence in favor of bachelor students since the t-value is -2.90 and the p-value is 0.004 which is less than 0.05.

3. There are no significant differences between students' types of intelligence that they prefer to use in learning English due to their academic degree program (bachelor/ diploma) on (a) linguistic intelligence, (b) spatial intelligence, (c) bodily-kinesthetic intelligence, (d) musical intelligence, (e) interpersonal intelligence, (f) intrapersonal intelligence. 
Table-3. T-test of students' preference for using each type of intelligence in learning English in terms of academic degree program (bachelor/ diploma).

\begin{tabular}{|c|c|c|c|c|c|c|}
\hline Type of intelligence & Degree & $\mathbf{N}$ & Mean & SD & $\mathrm{T}$ & P-Value \\
\hline \multirow[t]{2}{*}{ Total } & Diploma & 49 & 5.66 & 0.794 & \multirow[t]{2}{*}{-0.133} & \multirow[t]{2}{*}{0.894} \\
\hline & $\mathrm{BA}$ & 89 & 5.68 & 0.705 & & \\
\hline \multirow[t]{2}{*}{ Linguistic intelligence } & Diploma & 49 & 6.16 & 1.34 & \multirow[t]{2}{*}{0.279} & \multirow[t]{2}{*}{0.780} \\
\hline & $\mathrm{BA}$ & 89 & 6.10 & 1.20 & & \\
\hline \multirow[t]{2}{*}{ Logical-mathematical intelligence } & Diploma & 49 & 5.92 & 1.19 & \multirow[t]{2}{*}{-2.90} & \multirow[t]{2}{*}{$0.004 *$} \\
\hline & $\mathrm{BA}$ & 89 & 6.51 & 1.11 & & \\
\hline \multirow[t]{2}{*}{ Spatial intelligence } & Diploma & 49 & 5.84 & 1.25 & \multirow[t]{2}{*}{1.25} & \multirow[t]{2}{*}{0.215} \\
\hline & $\mathrm{BA}$ & 89 & 5.54 & 1.39 & & \\
\hline \multirow[t]{2}{*}{ Bodily-kinesthetic intelligence } & Diploma & 49 & 4.90 & 1.60 & \multirow[t]{2}{*}{0.038} & \multirow[t]{2}{*}{0.970} \\
\hline & BA & 89 & 4.89 & 1.48 & & \\
\hline \multirow[t]{2}{*}{ Musical intelligence } & Diploma & 49 & 4.80 & 1.73 & \multirow[t]{2}{*}{0.284} & \multirow[t]{2}{*}{0.777} \\
\hline & $\mathrm{BA}$ & 89 & 4.71 & 1.75 & & \\
\hline \multirow[t]{2}{*}{ Interpersonal intelligence } & Diploma & 49 & 5.73 & 1.51 & \multirow[t]{2}{*}{-1.53} & \multirow[t]{2}{*}{0.128} \\
\hline & $\mathrm{BA}$ & 89 & 6.12 & 1.38 & & \\
\hline \multirow[t]{2}{*}{ Intrapersonal intelligence } & Diploma & 49 & 5.90 & 1.23 & \multirow[t]{2}{*}{-0.050} & \multirow[t]{2}{*}{0.960} \\
\hline & $\mathrm{BA}$ & 89 & 5.91 & 1.44 & & \\
\hline
\end{tabular}

\section{Conclusions and Recommendations}

The following conclusions could be drawn based on the findings of the present study. First of all, the subjects of the present study preferred all types of intelligence in varying degrees, but the most preferred one was logicalmathematical intelligence. In contrast, the least preferred one was musical intelligence. This conclusion agrees with the findings of Tawalbeh (2016) whose study revealed that students do not tend to have interest in musical and naturalistic intelligence, which can be due to having a negative attitude towards music in general and with Yoones et al. (2014) whose subjects show preference of the interpersonal and logical-mathematical types. This conclusion is considered as a call for educators to develop teaching materials that incorporate the Multiple Intelligence Theory in all adults and children language learning classrooms and to make a shift from the traditional materials that focus mainly on some types like logical-mathematical and linguistic intelligence to other types like musical and spatial intelligence by preparing various tasks and activities that cover all the seven types of intelligence to meet the needs and abilities of the students. This goes in the same vein with Urooj and Malik (2012) who claimed that linguistic intelligence mostly predominates English textbooks, and they recommended promoting and incorporating other types of intelligence in English textbooks.

Second, gender does not significantly affect students' preference for the type of intelligence in learning English in general. However, there were significant differences due to the subjects' gender on the use of the interpersonal type of intelligence since it seems that male students tend to be more attracted to this type than their female colleagues. The researcher proposes that a possible explanation for this gradient is that female students tend to be less secure about communicating in English with others in the classroom. Moreover, findings of this study show that female students seem to depend on using the intrapersonal type of intelligence more than male students, this further suggests that females tend to be more autonomous than their male counterparts who can be viewed as more of extroverts and, or risk-takers.

Third, the academic degree program (bachelor/diploma) also does not seem to have a significant effect on the students' preference for the type of intelligence in learning English in general. However, there were significant differences due to the subjects' academic degree program (bachelor/ diploma) on the use of the logicalmathematical type of intelligence in favor of bachelor students. This conclusion could be attributed to the fact that most bachelor students in the present study are studying engineering. They originally had been in the scientific stream during secondary schooling, while the diploma students are from different streams such as the industrial, scientific, health, and literary streams.

Based on the conclusions obtained from the present study, several recommendations could be drawn. Firstly, English can be best taught if educators create effective and innovative ways of teaching that take into consideration the Multiple Intelligence Theory.

Secondly, textbooks for both university and school students should incorporate material, activities, and tasks that cover all the types of intelligence rather than focusing only on one or two traditional, common types, namely: linguistic and logical-mathematical types. This agrees with Botelho (2003) who concludes that the application of Multiple Intelligence Theory in children's textbooks is more apparent than in textbooks for adults, and this had proved that the activities in children's textbooks helped develop more types of intelligence than those in adults' textbooks. So, it is recommended to change the adult's textbooks to meet the needs of the learners and to include activities that target all types of intelligence.

Teachers are invited to examine their students' intelligence profiles before starting teaching, and to find out which type of intelligence is the most dominant among the students, and to prepare teaching materials and activities to support the English textbooks if they lack such activities to meet the needs, the learning styles, and the types of intelligence of the class in general and the individual students as well. Based on this recommendation, the researcher suggests that student intelligence type should be assessed through tools such as questionnaires derived from The Multiple Intelligence Theory and relevant literature. This goes in line with Alrabah et al. (2018); Dolati and Tahriri (2017); Kentab (2016); Xhomara and Shkembi (2020).

As for testing, there should be a shift from the traditional exams that cater to one or two common types of intelligence to focus on the other types that the students prefer to use in learning English. Thus, both students and teachers feel better, and so students are more positive towards learning English. This agrees with Altan (2012) who claims that The Multiple Intelligence Theory suggests that the traditional notion of intelligence, based on IQ testing, is far too limited. It also agrees with Sadiq (2019) who believes that the objective tests used to assess English mainly focus on memorization and that is because "teachers are less aware of using and applying MI theory 
in the field of teaching and assessing foreign language" (161). The theory proposes different intelligence to account for a broader range of human potential in children and adults. English language educators should be encouraged to include the theory into their programs and ways of testing.

To sum up, if educators want to have EFL learners who are proficient in English, they should be aware that students have different strengths and learning potentials. With incorporating the Multiple Intelligence Theory, they can create a more efficient and inclusive educational environment as well as an augmented learning curve demonstrating various needs of students being met.

\section{References}

Ababneh, S. (2017). Investigating individual learning strategies used by Jordanian EFL students. Studies in English Language Teaching, 5(4), 657-666.Available at: https://doi.org/10.22158/selt.v5n4p657

Abdul Razak, N., \& Zaini, N. (2014). Multiple intelligence scores of science stream students and their relation with reading competency in Malaysian University English Test (MUET). English Language Teaching, 7(2), 63-72.Available at: https://doi.org/10.5539/elt.v7n2p63.

Alqatanani, K. A. (2017). Do multiple intelligences improve EFL students' critical reading skills? Arab World English Journal, 8(1), 309321.Available at: https://dx.doi.org/10.24093/awej/vol8no1.22.

Alrabah, S., Wu, S.-h., \& Alotaibi, M. A. (2018). The learning styles and multiple intelligences of EFL college students in Kuwait. International Education Studies, 11(3), 38-47.Available at: https://doi.org/10.5539/ies.v11n3p38.

Altan, M. Z. (2012). Introducing the theory of multiple intelligences into English language teaching programs. Pamukkale University Journal of Education, 32(2), 57-64.Available at: https://doi.org/10.9779/puje474.

Arnold, J., \& Fonseca, M. C. (2004). Multiple intelligence theory and foreign language learning: A brain-based perspective. International journal of English studies, 4(1), 119-136.

Botelho, M. (2003). Multiple intelligences theory in English language teaching: An analysis of current textbooks, materials, and teachers' perceptions. Unpublished Master Thesis. Ohio University, The USA.

Brown, H. (2001). Teaching by principles: An interactive approach to language pedagogy (2nd ed.). White Plains, NY: Longman.

Brown, H. (2002). Strategies for success: A practical guide to learning English. White Plains, NY: Longman.

Derakhshan, A., \& Faribi, M. (2015). Multiple intelligences: language learning and teaching. International Journal of English Linguistics, 5(4), 63-72.Available at: https://doi.org/10.5539/ijel.v5n4p63.

Dolati, Z., \& Tahriri, A. (2017). EFL teachers' multiple intelligences and their classroom practice (pp. 1-12): Sage Open.

Gardne., H. (1999). Intelligence reframed: Multiple intelligences for the 21st century. New York: Basic Books.

Gardner, H. (1993). Multiple intelligences: The theory in practice. New York: Basic Books.

Kentab, M. Y. (2016). Saudi intermediate school EFL teachers' views in the Kingdom of Saudi Arabia of the multiple intelligences theory as an inclusive pedagogy. Journal of Education and Practice, 7(17), 105-122.

Kırkgöz, Y. (2010). Catering for multiple intelligences in locally-published ELT textbooks in Turkey. Procedia-Social and Behavioral Sciences, 3(1), 127-130.Available at: https://doi.org/10.1016/j.sbspro.2010.07.023.

Sadiq, B. (2019). The analytic domain of multiple- intelligence and its relation to english objective test. English Language Teaching, 12(5), 161-169.Available at: https://doi:10.5539/eltv12n5p161 https://doi.org/10.5539/elt.v12n5p161.

Snider, D. (2001). Multiple intelligences theory and foreign language teaching. Unpublished Doctoral Dissertation, University of Utah. The USA.

Sólmundardóttir, S. (2008). The multiple intelligences theory in English language teaching: Theme based lesson plans on Halloween. 1-56. Retrieved from: https://skemman.is/bitstream/1946/1485/1/adal_adal.pdf.

Tawalbeh, T. (2016). Investigating EFL learners' multiple intelligences in the preparatory year at Taif University. Theory and Practice in Language Studies, 6(7), 1346-1356.Available at: https://doi.org/10.17507/tpls.0607.03.

Urooj, T., \& Malik, S. (2012). Assessment of multiple intelligences managed in English textbook of primary level. International Journal of English and Education, 1(2), 153-169.

Winarti, A., Yuanita, L., \& Nur, M. (2019). The effectiveness of multiple intelligences based teaching strategy in enhancing the multiple intelligences and science process skills of junior high school students. Journal of Technology and Science Education, 9(2), 122-135.

Xhomara, N., \& Shkembi, F. (2020). The influence of multiple intelligences on learning styles in teaching and learning. Journal of Applied Technical and Educational Sciences, 1O(1), 19-48.Available at: http://doi.org/10.24368/jates.v10i1.148.

Yoones, T., Ahmadreza, M., \& Farzane, M. (2014). Intelligence profile of Iranian domestically designed and published ELT textbooks and students' multiple intelligences. International Journal of Language and Linguistics, 2(1), 24-31.Available at: https://doi.org/10.1016/j.sbspro.2010.07.023.

Yoones, T., Adnan, S., \& Hamid, S. (2014). Investigating students with English as a foreign language and their textbooks: an application of multiple intelligences theory. International Journal of Humanities and Social Science, 4(6), 285-294.

Zarei, A., \& Afshar, N. (2014). Multiple intelligences as predictors of reading comprehension and vocabulary knowledge. Indonesian Journal of Applied Linguistics, 4(1), 23-38.Available at: https://doi.org/10.17509/ijal.v4i 1.598. 